International Journal of Agriculture, Environment and Bioresearch

Vol. 5, No. 06; 2020

ISSN: $2456-8643$

\title{
PROBLEMS FACING SESAME PRODUCTION: A CASE STUDY OF HADEJIA LOCAL GOVERNMENT, JIGAWA STATE, NIGERIA
}

\author{
Zakar Yakubu \\ Department Agricultural Education, Kampala University, Kampala, Uganda \\ Shamsuddeen Hashim Yusuf \\ College Of Science And Technology, Jigawa State Polytechnic, Dutse, Nigeria \\ https://doi.org/10.35410/IJAEB.2020.5596
}

\begin{abstract}
The study was conducted to assess the problems facing sesame production in Hadejia LGA of Jigawa State, Nigeria. It adopted the Descriptive research method involving quantitative approach and self- administered questionnaire as instrument for data collection. A total of 60 farmers formed the study's sample size. Demographic results indicated that majority of the farmers were married young men within the age group of 25-45 years with very low level of education. Family sizes were found to be big and majority of the farmers were commercial farmers growing sesame for commercial purposes. Findings indicated that the major problem facing sesame production were poor agricultural extension services, theft and prevalence of pests diseases and poor marketing. Hence, it was conclude that, if drastic measures are not taken to addresses these challenges facing the production of sesame, these commercial farmers could be seriously affected financially as well as the state through loss of foreign exchange revenues because sesame is a cash crop majorly exported to other countries. Based on this conclusion it was therefore recommended that, government should strengthen agricultural extension services and provide farmers with improved seeds and agro- chemicals such as pesticides and insecticides in order to boost the farmers productivity
\end{abstract}

Keywords: Probnlems, sesame production, Hadejia, Jigawa, Nigeria.

\section{INTRODUCTION}

Sesame was the first oil seed cultivated by man in some part of African and Asian nations. The highest seed oil content is up to (48\%) make sesame one of the valuable seed oil crop grown. (Onwueme and Simha 1991).In West Africa, sesame is called beniseed and similar in east Africa. It is the crop from which semi-drying vegetable oils are obtained from its exception for one which is found in India. All the other nineteen (19) wild species of sesame are found in Africa this suggested that sesame (beniseed) was dominated and domesticated in Africa probably in Ethiopia, later speeds to India where it comes to be cultivated to a much greater extent, its place of origin.

Sesame in Africa becomes a secondary center of diversity development. Sesame (beniseed) appeared to have reached china century (AD) and was taken to the new world about 200years (Onwueme and Sinha 1991). Probably, sesame could have originated from Asia or East Africa 
but sesame is now found in most of the tropical and sub-tropical region, west Africa provide at least 0.05 million tons of sesame. The major producing countries are India, China, Korea, Bangladesh Asia, Sudan, Somalia, Nigeria, Uganda Ethiopia and Tanzania (extension guide No. 4). It is also grown in northern Tanzania. The main grow area in Nigeria includes; Benue Plateau and Kwara state (Extension Research Liaison Center, 1968).

\section{Background to the study}

Sesame seeds are mainly grown in the northern part of Nigeria. It is grown in States such as Benue, Kano, Jigawa, Katsina, Kogi, Nassarawa, Gombe Kebbi, Plateau, Bauchi, Taraba, Kaduna, Cross River, Kwara, Borno, Yobe, and ebonyi State etc. with Nassarawa being the major producer. While variety of Sesame seeds are mostly produced in Nassarawa and Benue States. The brown varieties are mostly produced in States like Kano, Jigawa, and Katsina. Local markets to source for Sesame seeds include Shaba, kantin kwari in Kaduna state and Gwaram in Jigawa and markets in Keffi and Laffia in Nassarawa State.

Nigeria exports as much as $22000 \mathrm{mt}$ (metric tons) of sesame seeds annually. Export volume from Nigeria to European countries is about 1900mt per annum. The world volume of exports and imports is about 560,000mt yearly with an annual growth rate of $2.6 \% 4 \%$ of this gross value is taken up by Nigeria and it is the second largest producer of Sesame seed in Africa and also ranked $7^{\text {th }}$ in the world. The figure below shows a sesame plantation.

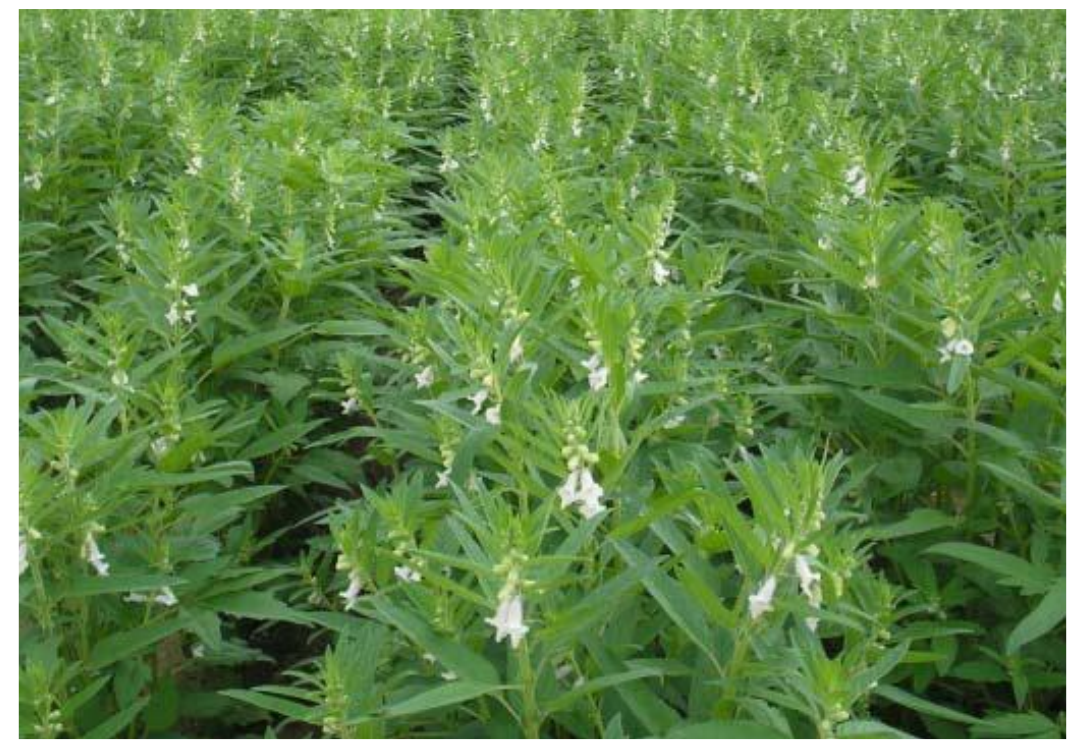

Figure 1: Sesame plantation.

However, the production of these economically important seeds is plagued by a number of problems which include both natural and anthropogenic as a result of which its productivity of is very low. Traditional production technology, climate change impact, insect pest and diseases, domestic and global market fluctuation and low research and expert knowledge and skill, are among the major challenges for sesame production in the world. 


\section{Statement of the problem}

Hadejia LGA is an agrarian society where many food and cash crop are being produced for both consumption and export. Crop normally grown there include millet, sorghum, corn, maize, rice, sesame etc. However, the production of many of these crop s especially sesame which is one of the major cash crops grown in the area is confronted by a number of both natural and human factors. Consequently, the productivity of sesame farmers is at record low. Most of the farmers are facing a lot of problems which leads them to the low production of beniseed in the area. Some $f$ these problems might not be unconnected with illiteracy, impacts of climate change, desertification, theft, poor technology and so on. Most of the farmers suffer from illiteracy which gives rise to inability to read and write. As the result of this, it brings a lot of stress and weakness in carrying out their farming operation effectively. They find it difficult to obtain and utilized innovations, ideas, skills and other necessary activities properly.

Moreover, the farmers in the study are having found it difficult to control pests and diseases which lead to low production of beniseed in the study area. Iruine (1999) stated that Nigeria pest diseases like grassphopper (pest) which destroys seedilings, caterpillars (pest) attack leaves. Moreover, lack of access to agricultural loan facilities has also weakened the farmers financially such that they are unable to farm good portions of their farmlands. Consequently, these peasant farmers could not afford improved seeds, fertilizers and pesticides, mechanized farming etc.

Therefore, it is against this background that this study was conducted with sole aim of assessing those problems that affect the production of the every important cash crop in one of the agricultural backbones of Jigawa states

\section{Purpose of the study}

The main objective of this study is to find out the major problems hampering the production of sesame in Hadejia Local Government Area of Jigawa state, Nigeria with the sole aim of suggesting possible solutions.

\section{Objectives of the study}

The specific objectives of the study are as follows

i. To determine the characteristics of sesame farmers in the study area

ii. To identify the major natural and anthropogenic hampering the production of sesame in the study area.

iii. To suggest strategic measures of addressing the problems facing the production of sesame in the study area.

\section{The study area}

HadejiaLocal Government Area (LGA) is of the 17 Local Government Areas that make up Jigawa State of Nigeria located in the North -Western part of Nigeria. It shares borders with GumelLGA to the North West;BornoState and Badde LGA to the North East;KatagumLGA of 
Bauchi State to the South and Kano state to the West. It lies between latitude $12 \mathrm{~N}$ and $13 \mathrm{~N}$ and between 10E and 50E. The area of Hadejia emirate is second largest emirate after Kano emirates in terms of population and land mass. It has area of $6,963 \mathrm{~km}^{2}$ and a population of 552,713 according to 2006.Hadejiaemirate comprises of eight districts namely;Auyo, Bulangu, Birniwa, Guri, Kaugama, Kafin-Hausa, Kirikasamma and MallamMadori districts. Major tribes in Hadejia LGA are the Hausas and the Fulanis who are found scattered all over the emirates. Others minor tribes are Manga, Badde, Gizim, and Koyam.

\section{MATERIALS AND METHOD}

The study adopted the Descriptive Research design involving Quantitative approach using Questionnaire as a data collection method and Self-administered Questionnaire as the data collection instrument. Data was analysed using Descriptive Statistics. A total of 60 sesame farmers were purposively selected to form the study's sample size.

\section{RESULTS AND DISCUSSIONS}

This section outlines the findings made by the study together with their interpretations as well as discussions made based on works of other scholars who conducted similar studies.

Table 1: Respondents' demographic characteristics

\begin{tabular}{|l|l|l|}
\hline Variables & Frequencies & Percentage \\
\hline Gender & & \\
\hline Male & 49 & $82 \%$ \\
\hline Female & 11 & $18 \%$ \\
\hline Marital status & & \\
\hline Marriage & 48 & $80 \%$ \\
\hline Single & 12 & $20 \%$ \\
\hline Level of education & & \\
\hline Primary School & 16 & $27 \%$ \\
\hline Qur'anic /adult education & 36 & $60 \%$ \\
\hline Secondary & 8 & $13 \%$ \\
\hline Others & - & - \\
\hline
\end{tabular}




\begin{tabular}{|c|c|c|}
\hline \multicolumn{3}{|l|}{ Age } \\
\hline $15-25$ years & 10 & 16.7 \\
\hline $26-35$ years & 11 & 18.3 \\
\hline $36-45$ years & 18 & 30.0 \\
\hline $46-55$ years & 15 & 25.0 \\
\hline $56-65$ years & 5 & 8.3 \\
\hline Above 65 years & 1 & 1.7 \\
\hline \multicolumn{3}{|l|}{ Family size } \\
\hline $1-5$ members & 0 & 0 \\
\hline 6-10 members & 22 & 36.7 \\
\hline 11-15 members & 28 & 46.7 \\
\hline $16-20$ members & 7 & 11.7 \\
\hline Above 20 members & 3 & 5.0 \\
\hline \multicolumn{3}{|l|}{ Tribe } \\
\hline Hausa & 26 & 43.3 \\
\hline Fulani & 4 & 6.7 \\
\hline Manga & 15 & 25.0 \\
\hline Ngizim & 10 & 16.7 \\
\hline Others & 5 & 8.3 \\
\hline
\end{tabular}

\section{Source: Field survey, (2019)}

From table 1 above, it can be discovered that majority of the sesame farmers were married men mainly within the age group of 26-55 years with very low level of education. Besides, the Hausa ethnic group was found to be the dominant and family sizes were also found to be big ranging between $6-20$ members. These findings agree with many other scholars' works which confirmed in traditional northern Nigerian setting, men usually dominate women when it comes to farming. In addition, majority of the men were married because it is the tradition of the people to marry at early ages. 
International Journal of Agriculture, Environment and Bioresearch

Vol. 5, No. 06; 2020

ISSN: $2456-8643$

Table 2: Respondents' occupational characteristics

\begin{tabular}{|c|c|c|}
\hline Variables & Frequency & Percentage \\
\hline \multicolumn{3}{|l|}{ Farming tools } \\
\hline The use of traditional tools & 30 & $50 \%$ \\
\hline Fully mechanized system & 20 & $33.6 \%$ \\
\hline Semi mechanized system & 10 & $16.4 \%$ \\
\hline \multicolumn{3}{|c|}{ Number of bags of fertilizer used every farming season } \\
\hline $1-5$ bags & 48 & $80 \%$ \\
\hline 6-10 bags & 12 & $20 \%$ \\
\hline $11-15$ bags & 0 & 0 \\
\hline 16-20 bags & 0 & 0 \\
\hline Above 20 bags & 0 & 0 \\
\hline \multicolumn{3}{|l|}{ Farm size } \\
\hline$<1$ ha & 16 & 26.7 \\
\hline $1-3$ ha & 38 & 63.3 \\
\hline $4-6$ ha & 6 & 10.0 \\
\hline Above 6 ha & 0 & 0 \\
\hline \multicolumn{3}{|l|}{ Source of labour } \\
\hline Family labour & 33 & $55 \%$ \\
\hline Hired labour & 27 & $45 \%$ \\
\hline \multicolumn{3}{|c|}{ Do you use other agro-chemicals } \\
\hline Yes & 35 & $53 \%$ \\
\hline No & 28 & $47 \%$ \\
\hline \multicolumn{3}{|l|}{ Type of farming } \\
\hline Subsistence & 9 & $15 \%$ \\
\hline
\end{tabular}


International Journal of Agriculture, Environment and Bioresearch

Vol. 5, No. 06; 2020

ISSN: $2456-8643$

\begin{tabular}{|l|l|l|}
\hline Commercial & 51 & $85 \%$ \\
\hline How was farmland obtained & \multicolumn{2}{|l|}{} \\
\hline Inherited & 21 & $35 \%$ \\
\hline Purchased & 16 & $26 \%$ \\
\hline Hired & 12 & $20 \%$ \\
\hline On lease & 11 & $18 \%$ \\
\hline
\end{tabular}

Source: Field survey, (2019).

As it is in many parts of the country, sesame production is mainly done on commercial bases as indicated above (85\%) on sizeable plots of lands ranging between 1-3 ha. However, due to their low economic status, majority of the farmers (50\%) use traditional farming equipment in the production of sesame and probably due to the increasing land degradation faced in this region in the form of desertification, almost all the respondents stated that they rely heavily on inorganic fertilizer for increased production. In fact, Jigawa State is one of the 11 northern states described as desert frontline states of Nigeria. One of the many consequences of land degradation is the increase in pests and diseases, this could be the reason why majority of the farmers make use of agro-chemicals including pesticides and insecticides. Family members were found to be the major source of labour while majority of the farmlands (35\%) were inherited.

\section{Problems facing sesame production}

As already stated above, the major objective of this study was to identify the main problems affecting the sustainable production of sesame in Hadejia LGA of Jigawa State, Nigeria. With respect to this objective, table 3 below depicts the major problems facing sesame production in the study area.

Table 3: Problems faced by sesame farmers (multiple response, $n=60$ )

\begin{tabular}{|l|l|l|}
\hline Problem & Frequencies & Percentage \\
\hline Pests/Diseases & 46 & 76.7 \\
\hline $\begin{array}{l}\text { Poor agricultural extension } \\
\text { services }\end{array}$ & 54 & 90.0 \\
\hline Lack/insufficient of fertilizer & 34 & 56.7 \\
\hline Poor storage facilities & 32 & 53.3 \\
\hline Drought & 36 & 60.0 \\
\hline Theft & 55 & 91.7 \\
\hline
\end{tabular}


International Journal of Agriculture, Environment and Bioresearch

Vol. 5, No. 06; 2020

ISSN: $2456-8643$

\begin{tabular}{|l|l|l|}
\hline Lack of formal education & 24 & 40.0 \\
\hline Poor marketing & 44 & 73.3 \\
\hline Inadequate land & 38 & 63.3 \\
\hline Lack of capital & 50 & 83.3 \\
\hline
\end{tabular}

Source: Field survey, (2019)

Findings indicated that the most serious problem facing sesame production in the study area was theft $(91.7 \%)$. Most often, this takes place when the sesame seeds are ready for harvesting. The culprits usually perpetuate the heinous activities at nights whereby the seeds were packed in bags and made away with. Consequently, at this stage, majority of the sesame farmers sleep on the farms guarding their produce. Trailing theft as one of the major problems facing sesame production was poor agricultural extension services with $90 \%$. Certainly, poor agricultural extension service is one of the major problems facing the agricultural sector in Nigeria. This becomes so serious issue because majority of the peasant farmers whose contribution to the nation's GDP cannot be neglected lacked any tangible level of western education so depend heavily on expert advises they get from agricultural extension services workers in order to boost their production. As at 2016, the ration of farmer to Agricultural Extension Service Worker was $1: 10,000$.

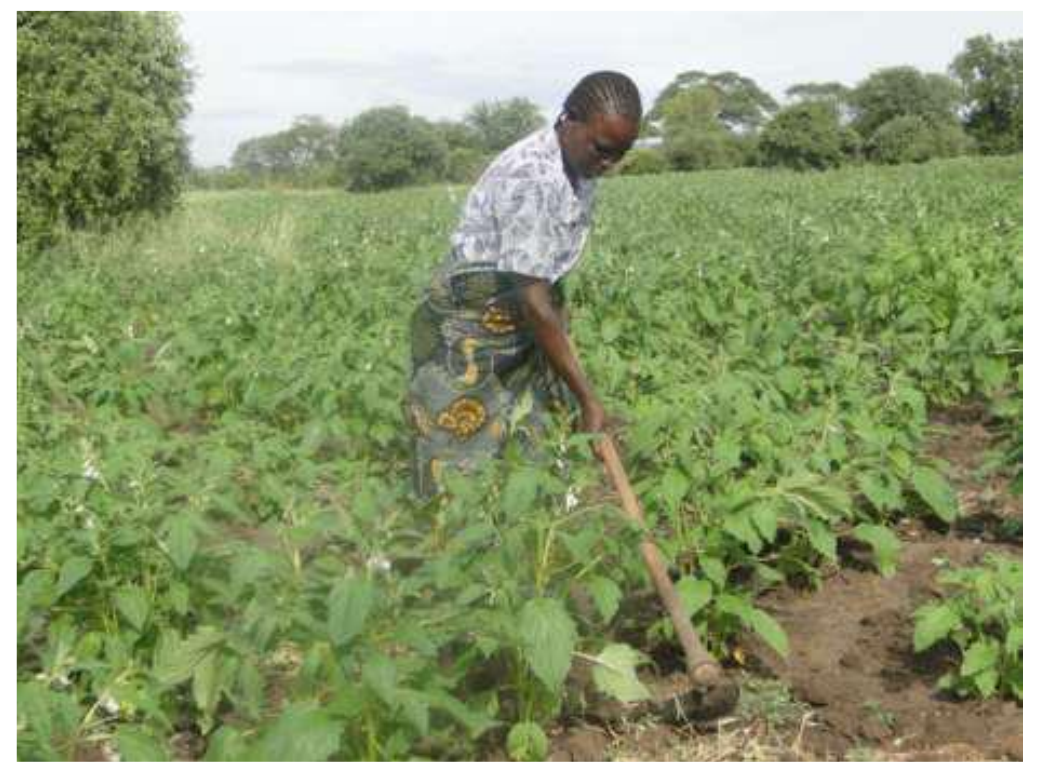

Figure 2: Farmer weeding in a sesame plantation.

One of the problems associated with capitalism is that the richer usually gets richer at the expense of the poor. This is manifested in the marketing of sesame seeds where the poor farmers were usually forced to sell their produce at cheaper prices because of poverty and lack of appropriate storage facilities. In most cases, farmers find it difficult to market their produce with convenience. Further worsening the plight of these poor farmers is the lack of capital. Sesame 
production is not cheap so requires a better capital base in order to survive it. Unfortunately, majority of these farmers were poor and do not get any form of financial from either the government or any other stakeholder. This corroborates the assertion by Erober (1998) that a lot of problems among countries in Africa and even the countries of the world are found to be factors that slow earning or getting better production of sesame. Similarly, Adeji (1989) also asserted that, local farmers are poor and do not have enough capital or money to money to buy farm inputs such as improved seeds, fertilizer, insecticide, herbicides and farm machineries.

Consequently, the farmers' productivity was seriously affected by insufficient fund. In addition, as stated above, Jigawa state is one of the 11 northern states described as desert frontline state in Nigeria battling desert encroachment from all angles. One of the characteristics of regions facing desertification is increasing drought possible due to climate change. Drought is known to be associated with little or total lack of rain when it is supposed to be there. Lately arriving or shortlived rainy seasons seriously affect sesame production sometimes leading to the total drying of the seedlings. Probably, the land tenure system does not favour sesame farmers much as majority of the lamented over insufficient land to cultivate. However, the respondents' occupational characteristics indicated that the sesame farmers had enough land to cultivate mostly ranging between 1- 3 ha. Possibly the lamentation over insufficient land could have stemmed out of the fact that the farmers could not expand their farms due to increasing land degradation or possibly due to strict and ineffective land tenure system,

Although the land is highly degraded, the farmers stated that by applying inorganic fertilizers, the level of their production was improved a bit however, the problems they do face was that of lack of these fertilizers or being insufficient when available. Thus, insufficient fertilizers significantly affected sesame production in the study area. Sometimes, the farmers were forced to dispose their produce at cheaper rates because of the lack of good storage facilities. Usually, farmers in this part of the nation store their produce in locally made granaries known as "Rumbu" which may not be so effective for the storage of sesame seeds. Hence, lack of good storage facilities poses serious threats to sesame farmers in Hadejia LGA. Another major problem facing sesame production is the emergence of pests and diseases which greatly affect the normal growth of the sesame plants. Consequently, the farmers use pesticides and insecticides to fight pests and diseases sometimes leading to indiscriminate and over use of the chemicals. Certainly, over use of agro-chemicals pose serious threats to the health of the environment thereby making the sesame production process environmentally unsustainable. 


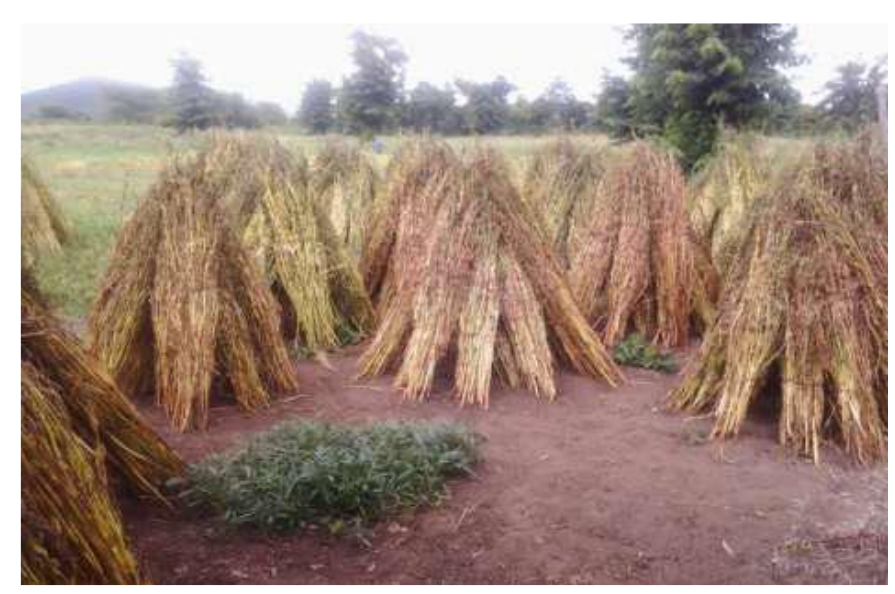

Figure 3: Bundles of sesame left to dry

As depicted in table 1 above, majority of the sesame farmers in the study area lacked any meaningful level of education. Being Muslim faithfuls, majority of them only had Quranic education. The importance of education in any endeavour not only in sesame production cannot be overemphasized. Hence, the farmers themselves believed that their low level of education is a threat of major concern affecting their profession.

\section{CONCLUSION}

Based on the findings made by the study, it could be concluded that sesame production is at serious stake due to threats posed by numerous problems including both natural and anthropogenic. This could have some consequences both on the farmers as well as the state in general. If left unchecked, the problems facing sesame production could lead to increase in abject poverty among the sesame farming communities. It should be noted that, this region has been describes as one of the poorest in Nigeria. Secondly, it can also pose certain threats to the issue of food security in the country In addition, sesame is one of the cash crop that earn foreign exchange to the country, hence, continuous reduction in sesame production due to the numerous problems plaguing its farming could spell doom to the nations GDP.

\section{RECOMMENDATIONS}

Based on the conclusion drawn above, the following recommendations are hereby proffered which could help a lot in addressing the problems facing sesame production in the study area:

- The government should provide improved seed to the farmers. Most especially in the rural area.

- The government should provide machineries for the farmers such as tractors, harvesters etc.

- The government to provide adequate fertilizers to the farmers.

- Government should provide chemicals such as pesticide, insecticide, and herbicides.

- Government and other agricultural financial institution should provide loans to farmers for soft or low interest rate. 
- Government should provide god road so that rural farmers can take their produce to the nearest market soundly.

- Government and agricultural marketing board should provide good marketing system to the farmers.

- Government should provide free education from primary to tertiary institution and more schools should be allocated to rural areas workshops and seminars.

- Government should provide adequate storage facilities for future use and increase it shelf life.

- Government should provide land and should make land available to the farmers. If possible government should lease their land cheaply to the farmers.

Farmer's stretch their supporting hands by getting their interest much more developed toward the production of the crop. They should give the high percentage of their cooperation to the government, extension workers and agricultural officers by listening, utilizing and obtaining successful resulting outcome.

\section{REFERENCES}

Adenji M.O. (1991) Countdown of agricultural science Lagos evainsbrorthers Nigeria Limited.

Ahuja, D.B. (2001). West African Crop. Third edition.California Oxford University.

Alegbejo, M.D, Ebo, M.E \&Idowu, A.A. (2003) Exam Focus for Senior Secondary Schools.

Ayemi I.A \&Kolawale, F.A (1997) Spectrum Memorable Guide: Agricultural Sciences of Senior Secondary School.

Onwueme\&Sinha, (1991) Contributions of some growth characters to seed yield of oil plants.

Iruine (1997) sesame production in Nigeria.

Triune (1999) Man, material, and machine tricycle for agricultural production.

Gibban (1985). Desertification has resulted in reduced food production and starvation.

Extension Guide No. 4, (1968) extension liason section Zaria institute for Agricultural research, AhmaduBelloUniversity Zaria.

Hill, D.S. (1975) Sesame: A potential industrial and exports of seed crop in Nigeria.

Erubour O. (1998) Comprehensive agricultural science for Senior Secondary School.

Raw materials research and development council (RMRDC) 2004 Survey report of ten selected agro raw materials in Nigeria.

M.U. Mustapha (2009).A short history of Hadejia Local Government. 